\title{
Histories of now: Listening to women in British film
}

\author{
by
}

\author{
Shelley Cobb and Linda Ruth Williams
}

\begin{abstract}
"How many filmmakers, female filmmakers, were making films when I came out [of the National Film and Television School]? Sally Potter ... a few in Europe ... three or four in America ... in the mainstream. ... I think my first film was either the third or fourth ever directed by a woman in in the UK, and one of the others was in the 30s or 40s. It was as good as nobody. Not to denigrate those women's work, but, I mean, in terms of feeling that you are something. ... In fact, on my first film, no member of the entire crew had ever worked for a woman director."

- Beeban Kidron ${ }^{1}$
\end{abstract}

'If ... history-making is recognized as an ongoing process in which the present dialogues with the past and cultural values are open to change, then the project of women's film history shifts focus from "archive" or "catalogue," conceived as place or receptacle, to archiving as a set of active, interventionist research practices in which we all participate?'

- Christine Gledhill

ABSTRACT:

The research project Calling the Shots: Women and contemporary film culture in the UK, 2000-2015 investigates contemporary women's film history through two primary routes: the statistical analyses of the numbers of women in six key above-the-line professions (director, writer, producer, executive producer, cinematographer and editor), and interviews with 50 women in those same roles (by August 2018 we had interviewed 58). One of the project's explicit aims has been to recover women's film history through these strands of primary research. This paper focuses specifically on the permutations of the interview process for constructing women's film history in the contemporary period, and considers the theoretical, methodological and political issues at stake in recording oral histories of working women filmmakers, 
contemplating how to and what the consequences are of collecting and writing history that is still in medias res.

Calling the Shots: Women and contemporary film culture in the UK, 2000-2015, our Arts and Humanities Research Council-funded research project, investigates contemporary women's film history through two primary routes: the statistical analyses of the numbers of women in six key above-the-line professions (director, writer, producer, executive producer, cinematographer and editor), and interviews with 50 women in those same roles (by August 2018 we had interviewed 58). ${ }^{3}$ One of the project's explicit aims has been to recover women's film history through these strands of primary research. This paper focuses specifically on the permutations of the interview process for constructing women's film history in the contemporary period. The interviewees agree to be identified, and almost all are filmed; they give consent to the process knowing that a filmed career overview will be placed in the Broadcasting, Entertainment, Communications and Theatre Union (BECTU) History Project Archive at the conclusion of the project. This award-winning archive holds interviews with people from the radio, theatre and entertainment industries dating back to the mid-twentieth century. ${ }^{4}$ Like the History Project Archive itself, our interviews therefore have a public-historic mapping role. During each interview the subject - or as oral historians often call interviewees, the narrator - is asked whether gender has affected their professional opportunities and the progress of their career. It is made clear through the preinterview consent process that they are free not to answer any question, but none the 58 narrators refused to answer this particular one. The answers are both multifarious and curiously consistent: Joanna Hogg, after outlining her many years as a TV director and her 
decision to leave that lucrative career to make her mark as a singular creative auteur with films like Archipelago (2010) and Exhibition (2013), discusses being repeatedly challenged by her predominantly male crews on the TV shows, and her consequent resolve to create her own team of collaborative colleagues, many of them female (and more comfortable with a woman director), on her film sets. Writer-director Clio Barnard addresses the potentially silencing phase of motherhood whilst using it to her advantage as a writer, but also describes being pushed towards producing early in her career, a role in which women have been marginally more successful, but not the one Barnard wanted. The Falling (2014) director Carol Morley discusses the silencing of not being offered projects by studios after her initial success, and how that resulted in a renewed creative capacity for becoming an auteur writer-director: since men are given the commissions to direct others' scripts, she says, then women will have to write and direct their own.

The original impetus for recording interviews with contemporary filmmakers was the idealistic (maybe even naïve) question: what if someone had recorded interviews with women working in the silent era while they were alive and still active? What if that collection of interviews were available to contemporary historians? How would film history, feminist film history, even feminist theory be different ${ }^{5}$ Since we could not change women's film history of the early twentieth century, we sought to at least record a part of twenty-first century history of women's filmmaking in the UK. ${ }^{6}$ Our research is part of a burgeoning interest in gender in the British film industry (Bell \& Williams 2009; Thornham 2012; Hockenhull 2017) and in women's creative labour (Conor et al, 2015) in the last ten years. Within this context, many of the responses to questions of gender and opportunity that the project has collected offer a particular and partial, but nevertheless significant, 
snapshot of women's experiences in the British film industry so far this century. The methods we are deploying push beyond the simple, though useful, documentation of transcribed interviews. Using approaches explored by recent oral historians (Abrams 2010), particularly ethnographic models for interpreting women's words (Gluck et al 1991), we make women's creative labour the central part of film history which it always should have been, starting by listening to the women themselves. In this article we will focus on the complexities underpinning that act of hearing as a building block in contemporary film history. Oral history of women's film work does, of course, exist in the BECTU archive's interviews with some women working below the line in various craft roles, in the practitioner interviews which are sometimes included in academic journals, and more recently in women filmmaker interview collections such as the US-focused In Her Voice: Women Directors Talk Directing (Women and Hollywood 2013), edited by Melissa Silverstein. Calling the Shots' interviews have been conducted in the contexts of these foundational precedents, while being focused on women's accounts of their work in a contemporary UK context-their collaborations, particular production contexts, and all stages of their creative labour, including work which remains as unproduced scripts or which has never made it past pre-production, as well as work which makes it to the screen. We facilitate career interviews that enable our narrators to discuss their mentors, their training, their completed work, their teams, their future plans.

We did not start this work as trained oral historians, but the dearth of information about women's work in contemporary cinema combined with an overarching desire to connect academic enquiry with film practice - and women filmmakers with film scholars meant formulating this part of the project as a way of generating new research materials. Film history documentation is often ephemeral, fragile and therefore quickly lost even for 
the most successful. British cinema archives rely on lucky acquisitions from independent or private collections, with no underpinning security of coverage or completion, with a few exceptions in areas such as the copious press clippings collected by the BFI Library. Some journals, such as the Journal of British Cinema and Television and Film Quarterly, include transcribed interviews with filmmakers, but again this is a snapshot approach to historical documentation. The interviews Calling the Shots is producing are generated by the venerated oral history approach of representing the underrepresented, and they are also part of a wider collecting movement which includes projects such as Melanie Bell and Vicky Ball's History of Women in the British Film and Television Industries, 1933-1989, which also engages with the BECTU History archive. Women's film history, built through oral articulations, is a dynamic process that binds filmmaker and researcher in a revaluation of gendered opportunities and creative labour within the British film industry today. All history is partial of course and written by dominant groups. Women's history is particularly punctuated by the silences of the unwritten. For historians of women in film, there has been a significant period since the early 1980s of 'filling gaps in an already established history of male inventors, moguls and great artists', but more recently we have been interrogating the question Christine Gledhill asked in 2010: 'does posing questions of gender change the way we do film history and therefore that history itself? ${ }^{7}$

In the epigraph above, Gledhill pushes further this question of gender and film history, challenging us to think of what we do as feminist historians as a mode of activismto think of the historian of women filmmakers as not just one who supplements the archives or textbooks, but as an active history-maker herself. Setting Gledhill alongside Beeban Kidron's narration of her personal history, the possibilities for both kinds of history making are made clear. On the one hand, our interview with Kidron is one way of naming her and 
adding her to film history (as the interview will be archived and used in books), but it also gave her the opportunity to articulate a history of women filmmakers, however limited the numbers were at the time, that she was joining and to see herself as a history-maker when she notes that none of her crew had worked for a woman director before. Her own version of history, constructed as it is by her memory of its affect on her, cannot now be changed. But her recorded history-telling now changes that historical moment when the numbers of women directors were 'as good as nobody' by inserting Kidron into that short list, which our interview does by inviting her to include herself in it and by recording her narration of that version of film history. Ultimately then, our interviews are focused at the intersection of the woman filmmaker who makes history and the history-making project of the feminist film historian. Both women filmmakers and women's film historians are 'history-making' and make history when they do the work they do, but particularly so in collaboration. We know this to be true, first because we know that there are so few women who succeed in filmmaking careers to this day; the act of filmmaking by a woman is still a history-making act. Second, this in turn impacts on women's film historians, who (re)make history when they find, speak with and write about the women who have made films. ${ }^{8}$

Both kinds of history-making are of course connected, through the investigative work of the women's film historian, ${ }^{9}$ (whether academic historian, amateur historian or filmmaker historian $)^{10}$ who searches for her subject - the woman filmmaker - researching her career, and making the historical (and often political) case for her and her films to be included in the archives, catalogues and histories of film. It is when the historian writes (or archives or films) her subject's history (however fragmented and filled with holes it may be) that the woman filmmaker's act of making history comes into being by being (partially) known by the historian herself and her readers/audience. This 'presence', or coming into 
existence, of the past in the present is interrogated by Jane Gaines' book Pink Slipped: What Happened to Women in the Silent Film Industries ${ }^{11}$ Gaines begins with Gertrude Stein who:

says that she does not know how the historian knows all that "he" knows. Neither does she know how the historian can "write" the no-longer-existing historical figure into existence, the moment of writing, and therefore the moment of the writer. She could have said that the only existence the past subject can have is the one given by the writer of history although that existence belongs not to the past but to the writer's present. ${ }^{12}$

These fraught historiographical questions are at the centre of Gaines's book and its articulation of the complicated history of developments within women's early film history. She argues that despite the absurdity of assuming that 'anyone would know enough from studying the historical evidence of events to write "this happened then"' or even to imagine that 'the historian "really knows everything"', we must hold onto the conviction that accepting the impossibility of knowing everything 'is not to suggest that there is "no knowing"', 13

These historiographic tensions depend in large part on the 'no-longer-in-existence' historical figure. But what if the woman filmmaker as the historian's subject still exists? What if the history we are trying to capture and write is ongoing in the living, working woman filmmaker? Are the possibilities of knowing everything better? Or are the difficulties of knowing anything simply different? And what does it mean to historicise the contemporary? As researchers on Calling the Shots we have interrogated these questions whilst recording our filmmaker interviews, and they animate our ongoing work as we try to 
theorise what we are doing, and hearing, as women's film history unfolds before us. This means that in the process of narrating their careers, our women filmmakers are also constructed by the historian's paradox of being the expert who knows things confronted with the impossibility of knowing everything. That this happens as we are video-recording our interview with them, which has the express purpose of putting women's film careers into the historical record, brings Gaines' point about the difficulty of knowing history into contact with Gledhill's call for interventionist historiography. This happens most clearly for us in the production of our oral history interviews. It is in the conversation between us as the listeners and the woman filmmaker as the narrator that the complexity of partial histories and their political potential become manifest.

Oral history has long offered "historians the opportunity to create documents where none existed and therefore rescue a hidden history." ${ }^{14}$ It is a long established strategy in women's studies:

Women's oral history, then, is a feminist encounter, even if the interviewee is not herself a feminist. It is the creation of a new type of material on women; it is the validation of women's experiences; it is the communication among women of different generations; it is the discovery of our own roots and the development of a continuity which has been denied us in traditional historical accounts. ${ }^{15}$

Listening to women tell their own stories and making them available for others is then a particular mode of history-making, one that is inevitably and, like all histories, incomplete. ${ }^{16}$ The questions we ask in interview, the time our narrators have to give to the process, the point in their career at which they speak to us, and the whole interactive exchange of address and response, all inform new histories that seem to definitively say 'this happened then', but which also expose gaps, spaces, and missed opportunities for both the filmmakers 
and for us as historians. Above all, we know we are listening, recording, and counting, in medias res.

\section{Conversations in medias res: "... and I just think 'why didn't I direct that?"}

However, the articulations of our interviewees not only address marginalisation or underrepresentation, but also offer career histories which sometimes include huge successes. These include directors Gurinder Chadha (Bend it Like Beckham, 2002; Bride and Prejudice, 2004; Angus, Thongs and Perfect Snogging, 2008; Viceroy's House, 2017), Beeban Kidron (Too Wong Fu, Thanks for Everything! Julie Newmar, 1995; Bridget Jones: The Edge of Reason, 2004) and Mandie Fletcher (Absolutely Fabulous: The Movie, 2016), as well as producers such as Debra Hayward (Les Misérables, 2012; Bridget Jones's Baby, 2016) and Elizabeth Karlsen (Made in Dagenham, 2010; Carol, 2015). We have also interviewed women right at the start of their careers, and women whose careers may have stalled because of institutional sexism or caring responsibilities. They are a diverse group, across a wide range of ages and career stages; independent, studio and mixed production; some highly senior women and some starting-out rookies. Nevertheless, all of our interviewees have one thing in common in that they are contemporary subjects. These are, then, histories of and within the present, generating specific questions around what is it to produce archive materials in medias res. Retrospection occurs, but it is qualified: all of our interviewees still consider themselves as flowing in career mid-stream, whether they are in their midtwenties and fresh out of film school, or approaching retirement. Even the late Anne V. Coates, who won an Oscar for editing Lawrence of Arabia in 1962, talked enthusiastically when we interviewed her in 2016 about her new role, aged 92, as a producer. This double framework of retrospection and future prospects generates a Janus-faced interview space: 
interviewees might exercise caution for fear of jeopardising subsequent employment (one disadvantage of the non-anonymous interview), and their backward-looking reflections are qualified not only by the contextualising forces of hindsight but also by the knowledge that they need to find work within the industry in the future.

This may raise questions about the 'truth' of the conversation, if future employment (or the benign light of posterity) rests on public, avowed utterance. However recent developments in oral history theory enable a more nuanced way of approaching how we do this mode of film history, and how we include the present, the now, in what we think of as 'history'. Since the 1990 s oral historians have thought more creatively about the textuality of the interview, recognising that as a developing field it has been most productive when drawing upon the methodologies of adjacent disciplines. Lynn Abrams writes, oral history is a subjective methodology... recognising that memory stories are contingent and often fluid, and in ... arguing that oral sources must be judged differently from conventional and documentary materials, but that this in no way detracts from their veracity and utility. In the process, oral historians have become both intuitive and imaginative interpreters of their materials. ${ }^{17}$

Oral history, she concludes, has been redefined as "an analytic practice as opposed to a method of recovery". One of the most incisive and lyrical writers in this area is Italian theorist Alessandro Portelli, who sees oral history as "what the source and the historian do together at the moment of their encounter in the interview", 18 which ideally will "connect [the source] with "history" and in turn force history to listen to them". ${ }^{19}$ As professional women with established public works, our interviewees are more like traditional historical sources than those oral historical narrators who tell stories of lives lived outside of the public sphere, at the margins of standard documentation. But as they slip from the personal 
to the professional and back again, the politics of what they are saying is audible. Portelli is useful again in distinguishing who is doing what work across the process:

The questions How historical is private life? and How personal is history? may be asked by the narrator, by the historian, or by both; indeed, the issue of what is private and what is public in a person's narrative is often uncertain, especially if we are after the elusive theme of the history of private life..$^{20}$

So whilst the history-and archive-building part of interview collecting is relatively straightforward (at its simplest, a way of shedding light on film-historical events through personal reflection), the actual production of them is rather less so. Thinking about this enables examination of our methods as well as the way that the interview 'conversation' (etymologically 'living among, abiding with') facilitates a form of self-interrogation by the 'narrator' which seems to articulate the personal, professional and political simultaneously. Calling the Shots, then, is both producing oral histories, and doing oral history. Our subjects are both the women's histories (which we are archiving), and the speakers' articulations of those histories.

But this article also addresses another, symptomatic but repeated moment which has occurred in the majority of our interviews. Throughout these multifarious encounters and for all the differences of the subjects as individuals - a remarkably common reflexive turn in the conversation occurs, when women articulate hesitation and experiences of incompletion, as well as achievement pinned to career chronology. At these points an untrodden path is tentatively - retrospectively - entertained, a turning-point is interrogated, a thwarted ambition unpicked, a decision is evaluated in light of all that led up to it or all 
that came after. Particular moments are revelatory here; specifically, what might seem to be reflections of and on uncertainty are, in fact, acutely politically articulate. These telling re-evaluations on the part of our filmmakers have emerged over the life of the project as an ever-more insistent, eloquently hesitant part of women's stories, often spoken with the nuances of hindsight and indignation at limited opportunity, even if articulated across many varied career histories and roles. We understand our interview work as part of a mutual process of making-history within the contemporary, and we would contest that these moments of hesitation are as much part of that as our filmmakers' statements of public achievement.

Two resonant examples include nuanced turning-points in our conversations with writer-director Amma Asante and playwright/screenwriter Moira Buffini. Our interviews are semi-structured, three-way conversations, usually including the two authors of this present article, and the filmmaker subject/narrator. When asked about a crucial meeting that seemed to reposition her from an in-front-of-the-camera actress to a behind-the-camera writer-director, Asante responded:

"Yes, I was empowered. And it has never struck me that in that moment I was actually empowered by women. It's only now as I tell you that story - and I could actually cry that I realise now that it was. And I don't know that they'd even remember me. And I say it was the beginning of a full circle moment because of course Belle, my second film, went on to be picked up by Fox Searchlight who bought it for the world at that particular point, so it was for me very much a full circle moment. But in that moment Yes - I went to behind the camera. I didn't know that that was what was happening. I wasn't aware of that. Yes it's true because I then literally wrote to my acting agent a few weeks later ... and I knew if I didn't write the letter and post it that day I might not 
ever do it. And I literally said 'Thank you very much for everything you've done for me. I don't want to do this anymore, and I'm going to look in a different direction'. I didn't know that [direction] would be writing, but all of these pieces, all of these disparate pieces, were going to somehow come together to guide me to this place".

The three-way conversation then develops to consider how Asante positioned herself in relation to a film history nearly empty of women, and particularly women of colour. Asante is a celebrated black British filmmaker with a strong public profile as a London-born woman with Ghanaian parents. Of the television series she discusses here that she was then writing (which never got made) and on which she sought to secure a producer credit she stated: "I hadn't seen anything on television that was like it, and I felt that it needed some authority who would understand the world that I was trying to create so that that world wouldn't then be changed by producers and a director. I had no concept of the idea of directing at that point - the idea that people of colour directing in the UK. I had one woman whilst I was on Grange Hill that directed me, but this was not the norm in any way, shape or form, so that didn't even come into it. But producers? I had seen female producers, I had seen female commissioning editors, so I just thought 'Alright, that's the one I'Il pick - I'll be a producer', not realising that actually what I was trying to do was see through the story, see through the characters I had created. That's what a director does, that's what an auteur does, but I didn't realise it at that point that that's what I was trying to hold on to."

Asante's words are replete with resonant awareness of hindsight, and an active apprehension of what has not yet been done, and what there is still to do. She is very selfconscious about gaps in conceptualising film roles, positions and achievements where there are none. Her hesitations are almost more politically significant than her definitive 
statements. We then ask her, 'So you had a sense of the job that you really wanted in relation to this project -- ' and she concludes the sentence for us: "--- I just didn't know what it was called. And if I had had an inkling of what it was called I would have pushed that out of my head because that was not a place that I would ever be able to get to".

A similarly symptomatic moment of hesitation occurs in our interview with Moira Buffini, when she addresses an old student film - a legacy from her undergraduate days, even though she did not attend film school:

"I found it on an old VHS in a box this summer and I thought '... I wonder if that stands up?' And I played it to myself, it's about twenty minutes long. And it's so me! - the screenplay - I just thought 'oh my God, there you go'! I didn't direct it, I wrote the screenplay and I sort of acted as assistant. And looking back on it it's quite strange - it wouldn't have occurred to me to put myself up to direct it, and I wonder how much of that was to do with my gender? - I wonder how much of it was to do with my gender? And I just think 'why didn't I direct that?'."

The self-questioning (indeed the rhetorically repeated questions on which this extract concludes) may reflect a spirit of rueful regret, despite Buffini's success as a screenwriter: when we interviewed her she was in the process of refocusing her energies towards directing. But it is also a genuine question of reflection and politicised repositioning. When we ask her if a male student directed that student film, she replies "Yes. I mean, he was great, we worked well together. But, yes, and I think it's quite a pattern. I think there were more women than guys on the course, but all of the assistants were women and none of them were men, as I recall. I may be mistaken..." - and then she concludes the trailing thought in a definitive tone: "but I think not". 
Amma Asante discusses career endings, beginnings, and unrealised writing projects, and Moira Buffini addresses what she didn't do in an old student film, reflecting on the difference between herself and the male director as students: "I was not aware of women directors. I was not aware". Asante reformulates a moment in her career when she rearticulated her career path, around an un-made commissioned series. So what kind of film history is this, with no conventionally documented film text, and with successful women filmmakers hesitantly articulating moments of career disruption? These are self-reflexive and interrogative, as past choices are contextualised by subsequent histories. They have a hesitancy that is uncharacteristic of a standard teleological career interview which more typically lays out public milestones and uses hindsight to rationalise order leading up to the present moment. ${ }^{21}$ But the interview itself is a collaborative and cumulative process; interviewees may remember or realise connections which only the process itself makes conscious. The interview is then both memory work and collaboration.

Of course production studies enables us to attend to this form of filmmaking labour as well as completed and theatrically released finished 'texts', providing some insights into the question of why some filmmakers are absent from the historical record, whether they disappeared from it, are hidden within it, or were never included in the first place. If, as it has been mostly the case, our primary record of filmmaking and film labour is the theatrical release, then vast amounts of filmmaking labour is excluded from film history. That includes both unmade films that linger at the state of treatment, unfinished screenplays, unfinished films or even finished films without an audience. As Natalie Wreyford has written of the screenwriter's work: 'most screenplays are never fully realized as films. This means that a significant percentage of many screenwriters' work is never seen by more than a handful of people'. ${ }^{22}$ This experience of filmmaking labour that is only seen or known by a handful of 
people is a feature of all aspects of film production. From script-editing and initial production planning to the acting, lighting, costuming, and directing of a scene left 'on the cutting room floor' in edit, most of the history of filmmaking is not reflected in the finished, released film. These bits of unseen filmmaking raise larger questions of absence regarding who counts as a filmmaker. As Wreyford goes on to ask: 'What then of those who don't even make it into the identifiable pool of workers known as screenwriters? How is it possible to critically examine those who are not even present ${ }^{23}$ Whether it is the writer who was employed by a studio but whose scripts were never produced or the script fixer without a credit or the wife of a famous director who effectively acted as a producer without recognition, much film history is always already absent if we only focus on the completed film text and its credits as the evidence of filmmaking labour. Early and silent film historians have known this for some time. ${ }^{24}$ We would argue that studies of contemporary cinema should follow their lead, searching out the hidden, lost, and seemingly minor parts of film history.

Clearly Asante and Buffini are highly 'present', which is what initially took us to them. But even in speaking about authoritative career histories there are resonant lapses of presence - often highly politically charged lapses - threaded through the narratives of public accomplishments and attained goals. Women filmmakers in particular can have long periods in between film productions or do work on a film that is taken over by a male filmmaker or write scripts that are optioned and not made. As Shelley Cobb argues elsewhere: 'just writing about the films women filmmakers do make leaves out whole portions of women's film history. A history that is the continuing fact of women's filmmaking...there are women's films throughout film history that have never been made. And these unmade films also have a history'. ${ }^{25}$ 
Practitioner interviewers can then do multiple things. They can help us to recover potentially lost evidence of working practices and contexts, but a more textual-analytic process opens up women's modes of articulating the meaning of what they do as well as the meanings of what they do not do. Calling the Shots' interview work is conducted in tandem with forensic statistical analyses of the numbers of women in those six key roles. When we put these two forms of data - the qualitative and the quantitative - side by side in a sense, we see the distinctions in the ways they make (or write) history. We see this most starkly in the figure of Asante, a successful black British woman director and the first black British woman director to have a film open the London Film Festival (A United Kingdom, in 2016). Asante has become an important representative of women's success in twenty-first British cinema. She is history-making in terms of public achievement, but our interview with her also records an individual nuanced history characterised by restarts, gaps, and achievements. And yet, our data show that of the 493 women who directed a British feature film between 2003 and 2015 (14\% of all directors), only 14 were black British. The data confirms how exceptional Asante's career has been, and reminds us that there are, no doubt, other black British women who have tried to be directors but have met insurmountable resistance. Our interviews show that many did not even realise one could aspire to be a director.

This article is not then primarily a plea for the power of inarticulacy, or a call-to-arms predicated on missed opportunity. It poses a set of questions around what we do know and can formulate about women's film history, but it also identifies work to be done, and the ongoing nature of that doing. Our data reports derive from a body of information which is itself in flux. Similarly, the time in which our interviewees speak - the $60-90$ minutes of each interview - is a fluid moment in a career read as work-in-progress. Some narrators are just 
starting out, some are established, all are still working, so therefore the self-interpretation of what they say is shifting, as are the interpretations of the historians they speak to. These interviews both are and are not retrospectives. This is alive work, and necessarily slippery.

\footnotetext{
${ }^{1}$ Beeban Kidron, Interview for Calling the Shots, London, 19th April 2017.

${ }^{2}$ Christine Gledhill (2010), 'Transnationalizing Women's Film History', Framework 51, 2, p. 281
}

3 Our interviewees are: directors Amma Asante, Clio Barnard, Rebecca Brand, Gurinder Chadha, Christiana Ebohon-Green, Jeanie Finlay, Mandie Fletcher, Sarah Gavron, Annie Griffin, Xiaolu Guo, Suzie Halewood, Joanna Hogg, Dictynna Hood, Beeban Kidron, Hope Dickson Leach, Kim Longinotto, Phillippa Lowthorpe, Jenny Lu, Morag Mckinnon, Amy Mathieson, Carol Morley, Rita Osei, Sally Potter, Susanna White; Producers Cairo Cannon, Pippa Cross, Sarah Curtis, Emma Davie, Finola Dwyer, Lizzie Francke, Laura Hastings-Smith, Debra Hayward, Sonja Henrici, Elizabeth Karlsen, Christine Langan, Ivana McKinnon, Al Morrow, Kate Ogborn, Amanda Posey; Screenwriters Smita Bhide, Moira Buffini, Lucinda Coxon, Norina Mackay, Kelly Marcel, Tess Morris, Juliette Towhidi; Editors Mags Arnold, Victoria Boydell, Anne V. Coates, Tania Reddin, Saska Simpson, Lucia Zuchetti;

Cinematographers Christine Lalla, Nina Kellgren, Martya Knitter, Annemarie Lean-Vercoe, Polly Morgan, Nanu Segal.

${ }^{4}$ See: https://bectuhp.wordpress.com

${ }^{5}$ The latter is a version of the question that Jane Gaines has been asking for some time, most recently in her book (2018) Pink-Slipped: What Happened to Women in the Silent Film Industries (Chicago: University of Illinois Press).

${ }^{6}$ In their 2017 article, 'Data and Responsibility: Toward a Feminist Methodology for Producing Historical Data on Women in the UK Film Industry', Wreyford and Cobb elaborate and interrogate the process of collecting, analysing and disseminating data on gender inequality in the film industry and articulate the feminist principles guiding Calling the Shot's 
approach to the process. Most relevant to our discussion here concerning the interviews as history-making is the assertion that 'according to the data, the main plot of the twenty-first century history of women's filmmaking so far is one of pervasive absence and exclusion: this is an important part of the history that must be told. However, as we've argued, it is not the whole story, and we seek to tell the rest the best we can with the qualitative data'. Natalie Wreyford and Shelley Cobb, 'Data and Responsibility: Toward a Feminist Methodology for Producing Historical Data on Women in the UK Film Industry', Feminist Media Histories, 3:2, pp. 110

${ }^{7}$ Christine Gledhill (2010) 'Transnationalizing Women's Film History', Framework, 51:2, p. 275

${ }^{8}$ The historian's work must be an activist intervention, because, as Shelley Stamp has argued, great and influential women like Lois Weber are regularly left out of 'standard' film history. Moreover Stamp also points out that if women of the present do not know that history, then 'today's generation of female filmmakers think they have to reinvent the wheel, when all they really have to do is look to the past for inspiration'. See: Shelley Stamp (2015) Lois Weber in Early Hollywood (Oakland, University of California Press): 3; and 'A Conversation with Shelley Stamp', Women Film Pioneers Project, accessed at: https://wfpp.cdrs.columbia.edu/2018/07/02/so-many-of-the-debates-were-having-todaywere-actually-settled-100-years-ago-a-conversation-with-shelley-stamp/ ${ }^{9}$ It is important to remember that the women's film historian may also be doing a similar kind of investigative and political work for female stars, female audiences, and women's genres and that all these can be history-makers as well. See Emily Carmen, Independent Stardom: Freelance Women in the Hollywood Studio (Austin: Universit of Texas Press, 2016); Shelley Stamp, Movie Struck Girls: Women and Motion Picture Culture after the Nickelodeon (Princeton: Princeton University Press, 2000); Jeanine Basinger, A Woman's View: How Hollywood Spoke to Women, 1930-1960 (Boston: Wesleyan University Press, 1993). ${ }^{10}$ Of course, these two ways of women's film history-making are, usually, distinct activities with different tools and different goals in different industries, often separated by time and space This is not always the case, however. There have been several films about the history of women's filmmaking since Anthony Slide's Not So Silent Feminists: America's First Woman Directors (1993), some of them by women, and since Laura Mulvey's (with Peter 
Wollen) Riddle of the Sphinx, some women academics have been filmmakers. Other films include: Sally Potter's Women Filmmakers in Russia [aka I AM AN OX, I AM A HORSE, I AM A MAN, I AM A WOMAN] (1990), to S. Louisa Wei's Golden Gate Girls (2013), to the very recent Half the Picture by Amy Adrion, which interviews contemporary women directors about the barriers they face now. Women scholars who are filmmakers have become much more common in the academy with the growth of practitioner research agendas.

11 Jane Gaines (2018) Pink-Slipped: What Happened to Women in the Silent Film Industries (Chicago: University of Illinois Press)

12 Jane Gaines (2018) Pink-Slipped: What Happened to Women in the Silent Film Industries (Chicago: University of Illinois Press): 1

13 Jane Gaines (2018) Pink-Slipped: What Happened to Women in the Silent Film Industries (Chicago: University of Illinois Press): 1

${ }^{14}$ Ronald J. Grele, "Directions for Oral History in the United States" in David K.Dunaway \& Willa K.Baum (eds), Oral History: An Interdisciplinary Anthology, Lanham MD: AltaMira Press 1996, pp. 62-84, p. 67.

${ }^{15}$ Sherna Gluck, "What's So Special About Women? Women's Oral History", in D.K.Dunaway \& W.K.Baum (eds), Oral History: An Interdisciplinary Anthology, Lanham MD: AltaMira Press 1996, pp. 215-230, p. 217, originally published in Frontiers: A Journal of Women's Studies, 2, summer 1977, 3-13.

${ }^{16}$ Our oral histories work in a complementary relationship with our project's data collection on the numbers of women working in British filmmaking in the twenty-first century. That data shows that women are severely underrepresented in British filmmaking, but it also creates a macro-history of women making British films by taking them into account as a group rather than as individuals, as we do in our interviews. The data is also inevitably an incomplete history. For more detail on how we think about its incompleteness and our methodology for collecting the data, see Wreyford and Cobb 2017.

${ }^{17}$ Lynn Abrams, Oral History Theory, London and New York: Routledge, 2010, p.6

${ }^{18}$ Alessandro Portelli, The Battle of Valle Giulia: Oral History and the Art of Dialogue, Madison, Wisconsin: University of Wisconsin Press 1997, p.3.

19 Portelli, p.viii.

20 Portelli, p.6. 
${ }^{21}$ An example of this might be the Faber Directors on Directors series, which historicises careers through chronologically sequenced collected interviews, often on a (theatrically released) film-by-film basis.

22 Natalie Wreyford (2018), Gender Inequality in Screenwriting Work, London:Palgrave Macmillan, p. 00.

${ }^{23}$ Wreyford p.00.

${ }^{24}$ See, for instance, Michele Leigh (2015) 'Reading Between the Lines: History and the Studio Owner's Wife' in Christine Gledhill and Julia Knight Doing Women's Film History: Reframing Cinemas, Past and Future (Chicago: University of Illinoi Press) 42-52.

${ }^{25}$ Shelley Cobb (2014) 'Women Directors and Lost Projects: writing the history of women's unmade films', Women's Film and Television History Network Blog, found at: https://womensfilmandtelevisionhistory.wordpress.com/2014/03/21/women-directorsand-lost-projects/ (01-10-18). 